blurred vision, other anticholinergic effects, or headache. Nausea persisted for three days after the overdose but had not been mentioned during treatment. This case provides further evidence of the safety of zimeldine in overdose.

[Sales of zimeldine in all countries were discontinued by Astra Pharmaceuticals in September 1983 because of the company's concern about reports of serious neurological side effects including the Guillain Barré syndrome.]

${ }^{1}$ Heel RC, Morley PA, Brogden RN, Carmine AA, Speight TM, Avery GS. Zimelidine: a review of its pharmacological properties and therapeutic efficacy in depressive illness. Drugs 1982;24:169-206.

2 Georgotas A, Mann J, Bush D, Gershon S. Safety data on zimelidine hydrochloride following an overdose. Acta Psychiatr Scand 1981;63, suppl $290: 257-61$.

${ }^{3}$ Emanuelsson B, Moore RG. Quantitation of zimelidine and norzimelidine in plasma using high-performance liquid chromatography. $f$ Chromatogr 1977;146:113-7.

${ }^{4}$ Coppen A, Rama Rao VA, Swade C, Wood K. Zimelidine: a therapeutic and pharmacokinetic study in depression. Psychopharmacol Bull 1979; 63:199-202.

${ }^{5}$ Vohra J, Burrows GD. Cardiovascular complications of tricyclic antidepressant overdosage. Drugs 1974;8:432-7.

(Accepted 22 fuly 1983)

Royal Melbourne Hospital, Parkville, Victoria 3052, Australia FIONA K JUDD, MB, BS, psychiatric registrar

Department of Psychiatry, University of Melbourne, Austin Hospital, Heidelberg, Victoria 3084, Australia

TREVOR R NORMAN, BSC, PHD, research fellow

GRAHAM D BURROWS, MD, FRCPSYCH, professor

Correspondence to: Dr T R Norman.

\section{Allergy to cows' milk presenting as chronic constipation}

Chronic constipation is common in early childhood. An organic cause may be shown in some children with it, and others show evidence of emotional disturbance. In most children, however, there are no obvious explanations for constipation. Allergy to cows' milk is a transient condition affecting mainly infants and young children who usually present with diarrhoea, vomiting, abdominal pain, and often a history of failure to thrive. ${ }^{12}$ Many other symptoms have been attributed to allergy to cows' milk, often with little objective evidence to support this.

We report on a child who was found to be allergic to cows' milk but who presented with constipation as the sole symptom.

\section{Case report}

A 34 month old boy had presented at the age of 17 months with a history of constipation of about one year's duration. He had been bottle fed from birth. He did not have a history of asthma or eczema. An older sister, his mother, and his maternal grandmother were intolerant of cows' milk, vomiting after drinking it. During early infancy he had had frequent "colic" but apparently normal stools. At 3 months he had had acute adenovirus gastroenteritis and his recovery had been delayed owing to persistent diarrhoea. He had been maintained on a protein hydrolysate feed (Nutramigen) for a month before a cows' milk formula was reintroduced.

At the age of 5-6 months his stools had become hard and he developed severe constipation, opening his bowels as seldom as twice in five weeks. A rectal biopsy showed normal ganglion cells and an abundance of eosinophils. He showed little response to treatment with a high fibre diet, large doses of senna, dioctyl sodium sulphosuccinate, and lactulose. He was admitted to hospital for management with enemas on two occasions but rapidly relapsed after discharge despite continuing laxative treatment.

Aged $2 \frac{1}{2}$ years he was started on a diet free of cows' milk and milk products. Within one week he had normal stools and a daily bowel action. The laxatives were stopped. Over a period of four months he had three milk challenges. On each occasion within 12 hours of drinking $200 \mathrm{ml}$ milk he became flushed, febrile, and miserable and complained of abdominal pain. His stools became hard and very small. After two days he had no further bowel actions. On withdrawal of cows' milk from the diet his symptoms rapidly disappeared with a return of normal stool frequency and consistency over the next 48 hours. Investigations showed a normal haemoglobin concentration and eosinophil count in the peripheral blood. Total serum IgE concentration was normal, and a specific IgE radioallergosorbent test for milk protein yielded weakly positive results.

\section{Comment}

There are no definitive tests for allergy to cows' milk, but it is accepted that diagnosis is best made by withdrawal of milk and challenge, preferably on more than one occasion.

The diagnostic criteria of Goldman et $a l^{3}$ for allergy to cows' milk require that (1) symptoms subside after withdrawal of milk from the diet, (2) symptoms recur within 48 hours after challenge with milk, and (3) these reactions occur with three such challenges and have similar onset, duration, and clinical features. Many physicians nowadays might regard these criteria as too strict, but few would doubt the existence of allergy to cows' milk in a child in whom they were fulfilled. Our patient's response fully satisfied these strict criteria.

Chronic constipation as a primary clinical manifestation of allergy to cows' milk is probably uncommon. Clein's study of 206 infants with allergy to cows' milk showed $10(6 \%)$ who had constipation that was not responsive to any laxatives and in whom normal stools followed complete withdrawal of cows' milk from the diet. ${ }^{4}$ No further information, however, was given about either any associated clinical features or the clinical response on subsequent challenges and withdrawals of milk. Buisseret, ${ }^{5}$ using Goldman's criteria to diagnose allergy to cows' milk, noted that, in addition to vomiting and abdominal pain, constipation was more common than diarrhoea as an associated symptom, although most of the infants also had either asthma or eczema. None of these patients, however, presented with constipation as the primary feature of their disease, and in all of them allergy to cows' milk was diagnosed on other grounds.

Our patient had chronic constipation unresponsive to laxatives. Regular bowel action was established, however, after cows' milk and milk products were withdrawn from the diet. We wonder how many young children with unexplained constipation not entirely responsive to usual treatment may be allergic to cows' milk.

1 Walker-Smith J. Diseases of the small intestine in childhood. 2nd ed. London Pitman Medical, 1979:149-54

${ }^{2}$ Bahna SL, Heiner DC. Manifestation. In: Allergies to milk. New York: Grune and Stratton, 1980:45-82.

${ }^{3}$ Goldman AS, Anderson DW, Sellers W, Saperstein S, Kniker WT,

Halpern SR. Milk allergy. I. Oral challenge with milk and isolated milk proteins in allergic children. Pediatrics 1963;32:425-43.

4 Clein NW. Cows' milk allergy in infants. Pediatr Clin North Am 1954; $4: 949-62$.

${ }^{5}$ Buisseret PD. Common manifestations of cows' milk allergy in children.

Lancet $1978 ; \mathrm{i}: 304-5$.

(Accepted 17 August 1983)

University of Birmingham, East Birmingham Hospital, Birmingham B9 5ST

K C CHIN, MRCP, DCH, lecturer

$M$ J TARLOW, MSC, FRCP, senior lecturer

Birmingham B34 6RB

A JOHN ALLFREE, MB, CHB, general practitioner

Correspondence to: Dr M J Tarlow.

\section{Immune complex nephritis complicating miliary tuberculosis}

Chronic caseous destruction and fibrosis are the pathological processes that usually affect the renal tract in tuberculosis. Recently, three immigrants with renal failure and pulmonary tuberculosis have been reported in whom urography showed none of the features of classical renal tuberculosis ${ }^{1}$; renal biopsy showed diffuse interstitial nephritis with caseating granulomas.

Since the advent of immunofluorescence and electron microscopic examination of renal biopsy specimens there do not appear to have been any reports of an association between tuberculosis and immune 
complex nephritis. We report on a patient with miliary tuberculosis complicated by immune complex nephritis.

\section{Case report}

A 45 year old Indian clerk presented in January 1981 with chest pain. Results of physical examination, electrocardiography, and chest $x$ ray examination were normal; urea concentration was $3.8 \mathrm{mmol} / \mathrm{l}(23 \mathrm{mg} /$ $100 \mathrm{ml})$ and creatinine $50 \mu \mathrm{mol} / 1(565 \mu \mathrm{g} / 100 \mathrm{ml})$; urine microscopy showed no abnormality and no protein. He presented again in July 1981 with a three week history of fever, night sweats, and weight loss $(4 \mathrm{~kg}$ over six months). Results of examination were again unremarkable: blood pressure $150 / 100 \mathrm{~mm} \mathrm{Hg}$; urea concentration $14.6 \mathrm{mmol} / 1(87.8 \mathrm{mg} / 100 \mathrm{ml})$; creatinine concentration $256 \mu \mathrm{mol} / 1(2.9 \mathrm{mg} / 100 \mathrm{ml})$; and creatinine clearance $30 \mathrm{ml} / \mathrm{min}$ (figure). Urine microscopy showed $40 \times 10^{6}$ red blood cells $/ 1$ and no white blood cells; urine protein excretion was $1.3 \mathrm{~g} / 24$ hours. Chest $x$ ray examination showed right basal and widespread miliary shadowing; results of intravenous pyelography were normal. Sputum, early morning urine, and gastric washings were negative on microscopy for tubercle bacilli. Mantoux testing yielded a negative result ( 1 in 100). C3 and C4 concentrations were normal. Liver biopsy showed epithelioid cell granulomas with central caseation; occasional tubercle bacilli were shown by Ziehl-Neelsen staining.

Four weeks later Mycobacterium tuberculcsis, fully sensitive to antituberculosis drugs, was isolated from sputum and liver samples. Renal biopsy after three weeks' treatment with isoniazid, pyrazinamide, and rifampicin showed focal proliferative glomerulonephritis with granular mesangial staining for IgA and IgM; intense staining for $\mathrm{C} 3$ was present in the mesangium and around capillary loops. Granulomas were not seen amyloid stains yielded negative results. Circulating immune complexes were detected by macrogol (polyethylene glycol) assay at $190 \mu \mathrm{g} / 1$ (normal $<100 \mu \mathrm{g} / \mathrm{l}$ ) but not by Clq binding assay; plasma C3d concentration, a measure of complement activation, was $25^{\circ} 5^{\circ}{ }^{\circ}$ (normal $<210^{\circ}{ }^{\circ}$ of a fully activated serum standard). ${ }^{2}$ Circulating immune complexes and $\mathrm{C} 3 \mathrm{~d}$ concentrations fell and were normal after three months of antituberculosis treatment. The fever took five weeks to resolve. Prednisolone was added to the treatment after four months (figure).

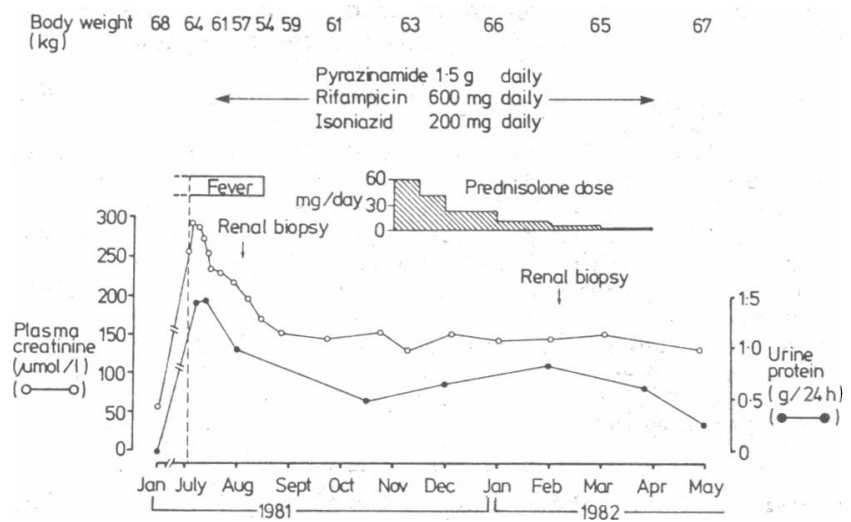

Clinical course of treatment with antituberculosis drugs.

Conversion: SI to traditional units-Creatinine: $1 \mu \mathrm{mol} / 1 \approx 11.3 \mu \mathrm{g} / 100 \mathrm{ml}$

Six months after diagnosis a second renal biopsy showed segmental scarring but no hypercellularity of glomerular tufts, and immunofluorescence testing yielded negative results. Fifteen months after diagnosis he was well and his renal function had improved: urea concentration was $6.8 \mathrm{mmol} / 1$ $(40.8 \mathrm{mg} / 100 \mathrm{ml})$; creatinine concentration $167 \mu \mathrm{mol} / 1(1.9 \mathrm{mg} / 100 \mathrm{ml})$; creatinine clearance $56 \mathrm{ml} / \mathrm{min} ; 24$ hour urine protein $0.2 \mathrm{~g}$; and results of urine microscopy normal. Mantoux test results had become positive at 1 in 1000 .

\section{Comment}

Patients with acute febrile illnesses may develop proteinuria that disappears on recovery. This "febrile proteinuria" has sometimes been ascribed to a non-specific response to the febrile state. In certain acute infections, however, renal biopsy has shown an immune complex nephritis. ${ }^{3}$ This does not appear to have been described in patients with tuberculosis.

It has been proposed that there is a clinical and immunological range of tuberculosis analogous to that of leprosy. ${ }^{4}$ Patients reactive to tuberculin and with localised lesions have neither free mycobacterial antibody nor immune complexes in serum; patients who are not reactive but have acute miliary disease have immune complexes and high levels of antibody. ${ }^{4}$ Our patient with immune complex nephritis appears to be at the "lepromatous" end of the immunological spectrum whereas the patients of Mallinson et al ${ }^{1}$ with localised reactive disease may be placed at the "tuberculoid" end.

Immune complex nephritis has been reported in patients with lepromatous leprosy. ${ }^{5}$ Such patients are not unlike our patient as they also show evidence of circulating immune complexes and complement activation and are unreactive to lepromin.

Dr M Wansbrough-Jones, St George's Hospital Medical School, kindly performed plasma C3d assays.

Mallinson WJW, Fuller RW, Levison DA, Baker LRI, Cattell WR. Diffuse interstitial renal tuberculosis-an unusual cause of renal failure. Qf Med $1981 ; 50$ (198): 137-48.

Perrin LH, Lambert PH, Mischer PA. Complement breakdown products in plasma from patients with systemic lupus erythematosus and patients with membranoproliferative or other glomerulonephritis. $\mathcal{F}$ Clin Invest $1975 ; 36: 165-76$

${ }^{3}$ Rainford DJ, Woodrow DF, Sloper JC, de Wardener HE, Griffiths I. Post meningococcal acute glomerular nephritis. Clin Nephrol 1978; 9:249-53.

4 Brostoff J, Lenzini L, Rottoli P, Rottoli L. Immune complexes in the spectrum of tuberculosis. Tubercle $1981 ; 62: 169-73$

${ }^{5}$ Iveson JM, McDougall AC, Leathem AJ, Harris HJ. Lepromatous leprosy presenting with polyarthritis, myositis and immune-complex glomerulonephritis. Br Med 7 1975;iii :619-21.

(Accepted 2 August 1983)

St James's Hospital, Balham, London SW12, and St George's Hospital Medical School, London SW17

J H SHRIBMAN, MB, MRCP, medical registrar

J B EASTWOOD, MD, FRCP, consultant renal physician and senior lecturer J UFF, MRCP, MRCPATH, consultant in histopathology and senior lecturer

Correspondence to: Dr J B Eastwood, St George's Hospital, London SW 17.

\section{Oxygen hazards in divers breathing helium and oxygen mixtures}

The technology of hyperbaric life support has advanced over the pas two decades with the growing commercial importance of diving in exploration for and production of oil from the sea bed. Related medical practice in the United Kingdom serves probably more than 2000 commercial divers, who work mainly for the North Sea oil industry. British regulations forbid the use of compressed air when diving below $50 \mathrm{~m}$ of seawater ${ }^{1}$ and impose the need for an artificial atmosphere, typically of $40 \mathrm{kPa}(0.4 \mathrm{bar})$ oxygen with the balance largely helium." A diving operation is complex and requires teamwork to support divers inside a saturation chamber for 30 days or more Divers depend on life support technicians, who control their environment and comfort from a console outside the chamber. There is an analogy between life support technicians and anaesthetists, both of whom are responsible for ensuring inter alia that their charges receive an appropriate partial pressure of inspired oxygen.

\section{Case reports}

Case 1-When the lock was opened after decompression of a chamber filled with a helium and oxygen mixture two divers were found unconscious on the chamber floor by a life support technician. He too collapsed on entering the chamber, and it was rapidly recompressed with air to $400 \mathrm{kPa}$ ( 4 bars), with recovery of the occupants. Before the lock was opened air should have been piped into the chamber to displace the helium and oxygen mixture, but a helium valve had been opened before the sea was broken and pure helium, instead of air, had been piped in. The occupants had lost consciousness for some minutes owing to hypoxia, but their position on the floor may have kept them in a layer of helium and oxygen because its density is greater than that of pure helium.

Case 2-At a depth of $190 \mathrm{~m}$ of seawater a diver was working outside his diving bell and became alarmed when his colleague inside did not reply on the communications system. On returning to the bell he found his colleague semiconscious and slumped on the floor. He closed the hatch, and the bell was winched to the surface and locked to the deck decompression chamber of the diving support vessel in the usual way. Examination of the bell later showed a faulty tracking regulator in the oxygen supply line, which had resulted in undetected leakage of pure oxygen into the bell through the sensing line. The bellman had lost consciousness while squatting over the 